\title{
Emission and Performance Characteristic of Biodiesel Burner System: A Review
}

\author{
Latip Lambosi $^{1, a}$, Amir Khalid ${ }^{1, b}$, Bukhari Manshoor ${ }^{1 \mathrm{c}}$ \\ ${ }^{1}$ Combustion Research Group (CRG), Centre for Energy and Industrial Environment Studies \\ (CEIES), UniversitiTun Hussein Onn Malaysia, Parit Raja, Batu Pahat, 86400 Johor, Malaysia \\ alatiplambosi@gmail.com, bamirk@uthm.edu.my, 'bukhari@uthm.edu.my
}

\section{Key Words: Biodiesel, Burner, Emission, Combustion, NOx}

\begin{abstract}
Shortage in hydrocarbon fuel sources, energy preservation and future stringent emission regulations have been a formidable challenge to the most prominent Small and Medium Enterprise (SME ) in Malaysia especially in the burner system of boiler. Therefore, the alternative source of fuel is receiving a lot of attention especially in the application of renewable energy such as biodiesel fuel (BDF) and low quality fuel. The application of biodiesel in the burner system offer not only attractive and more economical fuel but also creates problems of higher toxic emission such as nitrogen oxide (NOx), carbon monoxide (CO) and particulate matters (PM). This review presents the current status of the several studies that had been carried out on the emission and performance characteristic of biodiesel burners burner in term of the specific fuel type that could be used, type of emissions such as $\mathrm{NOx}, \mathrm{CO}, \mathrm{CO} 2$ and others operating condition that can be used to optimize the performance of the biodiesel burner system and also comment the progress of it in some areas. Based on the review clearly indicated that this form of alternative fuel can be an attractive renewable alternative energy source for burner system.
\end{abstract}

\section{Introduction}

The demanding growth of alternative energy sources costs have resulted the rising concerns about the environmental impacts of fossil fuels and their future availability. While being able to meet the energy demands for an ever-expanding global population, these sources must be sustainable and economically practical for large-scale implementation. Biodiesel is a promising alternative fuel to petroleum diesel because it had comparable properties to the common diesel, but with the added advantage of being renewable due to its biomass origin[1]-[3].

The behavior of biodiesel in the internal combustion is had been investigate intensively around the world, but a few study on the behavior of biodiesel in burner and furnace. Generally burner function is to provide a stable operation and acceptable flame pattern over a specific set of operating condition. One of the operating conditions of a burner is to use specific type of fuels[4] and in this case biodiesel fuel. The biodiesels derived from different plant oils will have slightly different molecular structures such as carbon-chain lengths, hydrogen-carbon ratio and oxygen content due to the variation of the degree of unsaturation of the fatty acids in different sources[5]-[7].

These fuels can be available in burner easier than other combustion equipment. However, the application of low quality fuel in the burner system offer not only attractive and more economical fuel but also generates complications of higher toxic emission such as nitrogen oxide (NOx), carbon monoxide (CO) and particulate matters (PM) compared to standard petroleum based diesels[8]-[11]. Thus, there is a need for tests to characterize the performance and emission properties of the biodiesel burner system.

\section{Biodiesel as Alternative Fuel.}

It is vital that the fuel used should match the burner. Using fuels with improved characteristics do not certainly increase burner performance. The fuel characteristics would depend on burner type, size, design and operating conditions[12]-[14].By using fuels with characteristics below the minimum burner requirements can cause rough burner operation. The need of different burner settings for optimum performance for the usage of biodiesels may vary in composition and purity 
from different feedstock. For example, the atomization and affect the air-fuel mixing rate can influence the fuel density and viscosity. Low viscosity fuel is easier to inject, atomize and mix with air. As such the viscosity will affect the spray angle[15]-[17].

There are remarkable opportunities for refining the physical characteristics of biodiesel. The key to improving the quality of biodiesel may well lie in finding suitable ingredients with the right proportions of fatty acids as well as developing optimal catalysts and processes to transform the feedstock into biodiesels with desired properties. The different qualities of biodiesels with slightly different properties can be produce from a feedstock with diverse proportions of saturated, monounsaturated, and polyunsaturated fatty acids[18]. On the other hand, unsaturated fatty acids containing one or more reactive double bonds can significantly increase the tendency to undergo oxidation degradation and increase the NOx emissions[19].

\section{Characteristics of Biodiesels Emissions on Burner}

Most of the biodiesels emit more NOx than diesel although there are cases where the opposite occurs. The amount of NOx produced would depend on the nitrogen and oxygen content in the biodiesels as well as the combustion dynamics, which can be influenced by the adiabatic flame temperature, duration of high burning gas temperature and sprays characteristics[20], [21]. The increasing of biodiesel proportion will increase NOx[22], [23].

The addition of other substance together such as ethanol, water or other additive to the biodiesel resulted in significant decrease in smoke emission compared to diesel[22], [24]-[26].

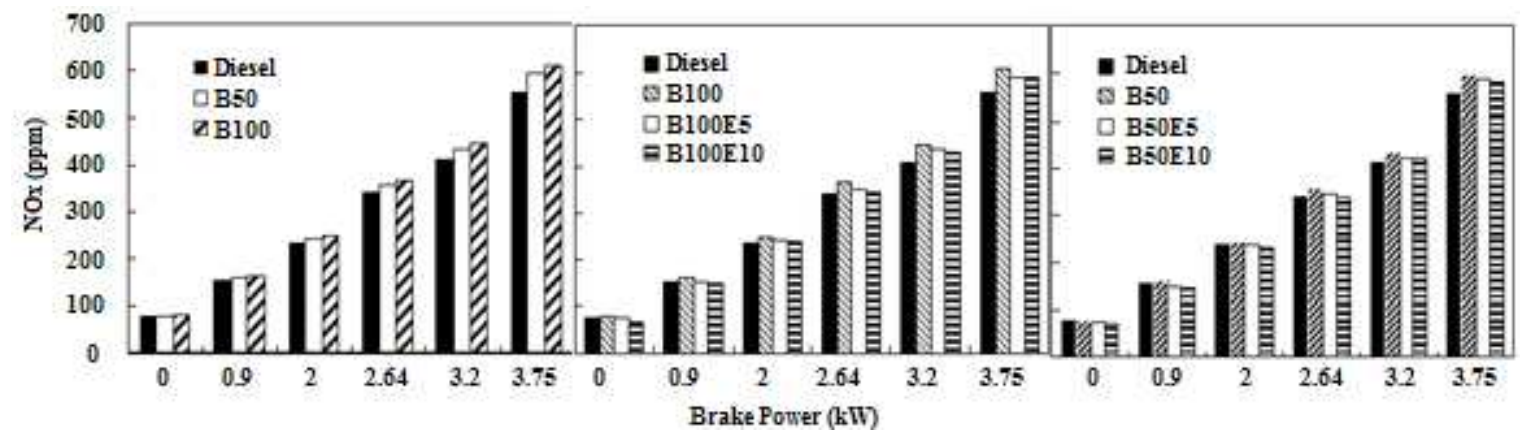

Figure 1: NOX emission before and after the addition of ethanol to B100 and B50 fuels[27]

The variation of NOX emission at various power outputs for B50 and B100 fuels is shown in Figure 1. The NOX emission is found to decrease with ethanol addition. It is concluded that the addition of ethanol with biodiesel fuels can extend the availability of diesel and reduce the NOX and smoke emissions simultaneously. Due to presence of oxygen and low heat content of ethanol the author claim that brake thermal efficiency for biodiesel blend with ethanol was lower than diesel and biodiesel at all loads[27].

Figure 2 compares the water additional into hydrocarbon fuel such as methane, kerosene, diesel, and biodiesel has potential to reduce pollutant emission (NOx, Sox and soot) depend on the type of experiment methods. Almost all researchers studied the fuel emulsions. The benefits of water emulsions are improve the combustion efficiency, reduction of the particular matter (PM) and NOx emission. Water-emulsification is one of easier and lower cost solution of toxic emission in burner combustion. Water-emulsified fuel reduces the flame temperature, leading to NOx reduction that had been tested by Kidoguchi, Yatsufusa. For HC cases, the increasing amount of water affects to decreasing of HC at all loads due to 'micro-explosion' that occurs when the volatility difference between water and diesel that results to violent disintegration of fine droplets and enhances fuel-air mixing in combustion chamber to reduces sort and HC[28]-[31]. 

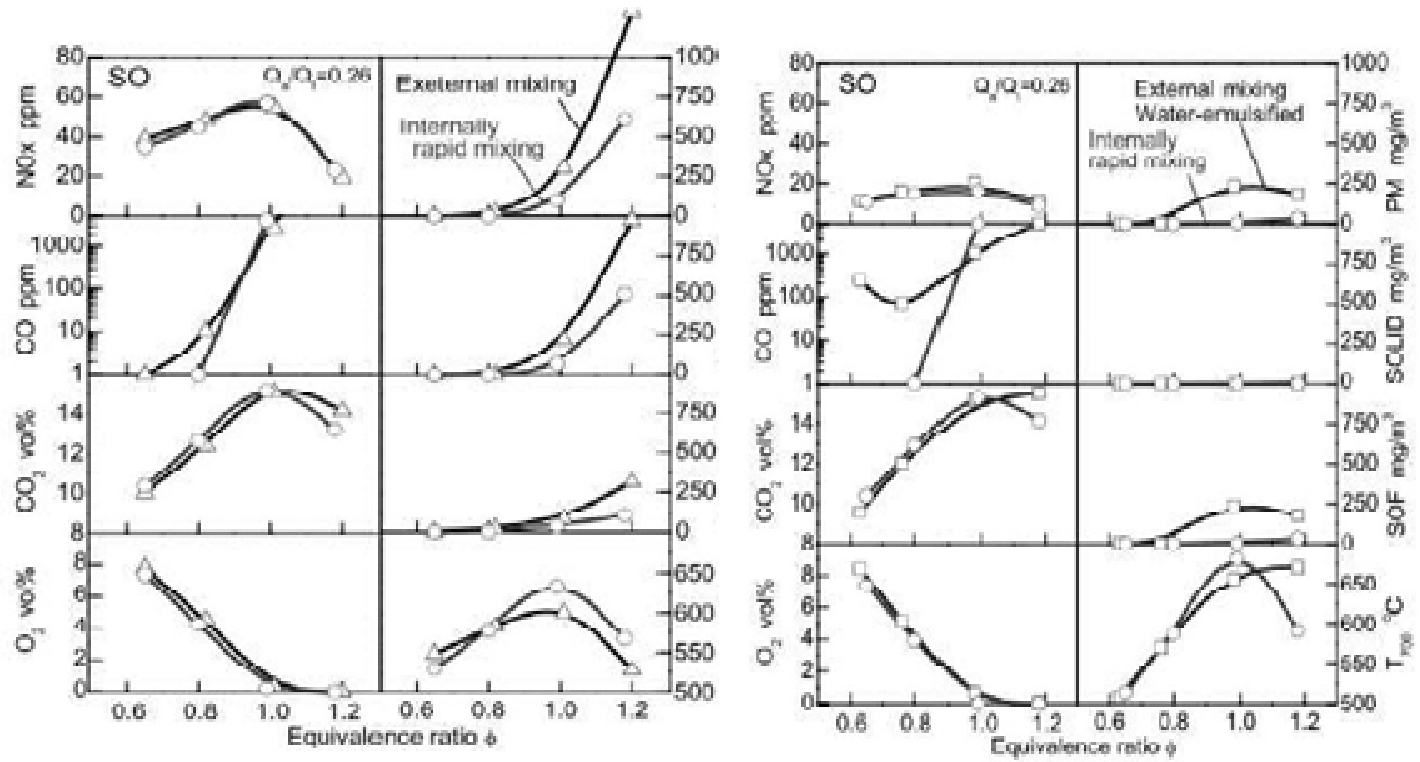

Figure.2:Effects of water content on emissions[28]

$\mathrm{CO}$ is one of the consequences of incomplete fuel combustion. Figure 3 shows the average percentage change in $\mathrm{CO}$ for different biodiesels after the engines were switched from diesel to operate on the biodiesels. Less $\mathrm{CO}$ is generated with biodiesels than diesel. Concentration of oxygen during combustion would enhance the oxidation rate of $\mathrm{CO}$ and lead to less $\mathrm{CO}$ formation. This is a major advantage of oxygenated fuels like biodiesel. It should be noted that the carbon contents of different biodiesels are not the same and most biodiesels have less carbon content than diesel. This could also affect the percentage change in CO emissions[32], [33].

Figure 4 the shows the comparison between BD20 and BD50 in terms of combustion efficiency and $\mathrm{CO} 2$ emission reduction due to the use of distillate and biodiesel. The author claimed that biodiesel is carbon neutral and that the combustion of this fuel does not contribute $\mathrm{CO} 2$ emission to the atmosphere because the carbon released is equal to the carbon absorbed by plants. Therefore, users would need to evaluate the main priority in the system, whether they would compromise for the efficiency or the $\mathrm{CO} 2$ emission[20].

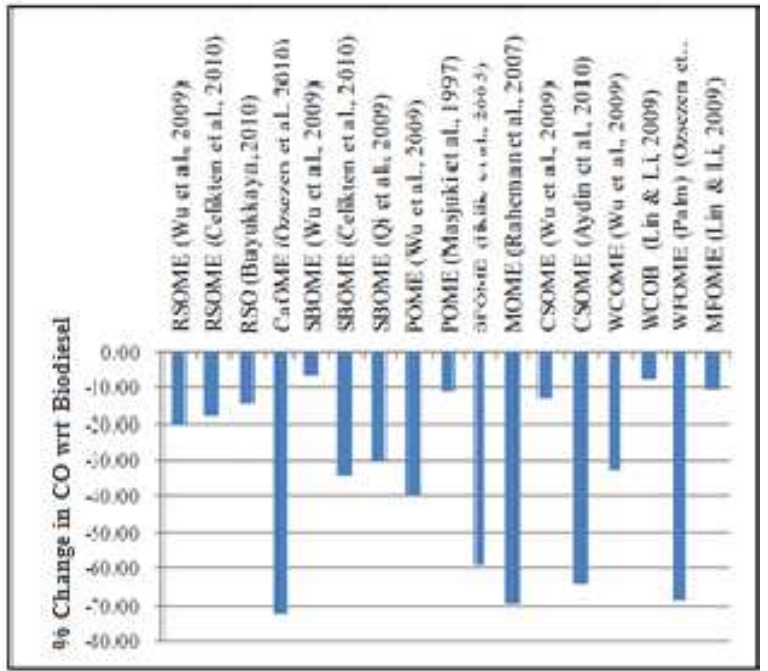

Figure 3: Comparison of average percentage change in $\mathrm{CO}$ with different biodiesel wrt diesel[33].

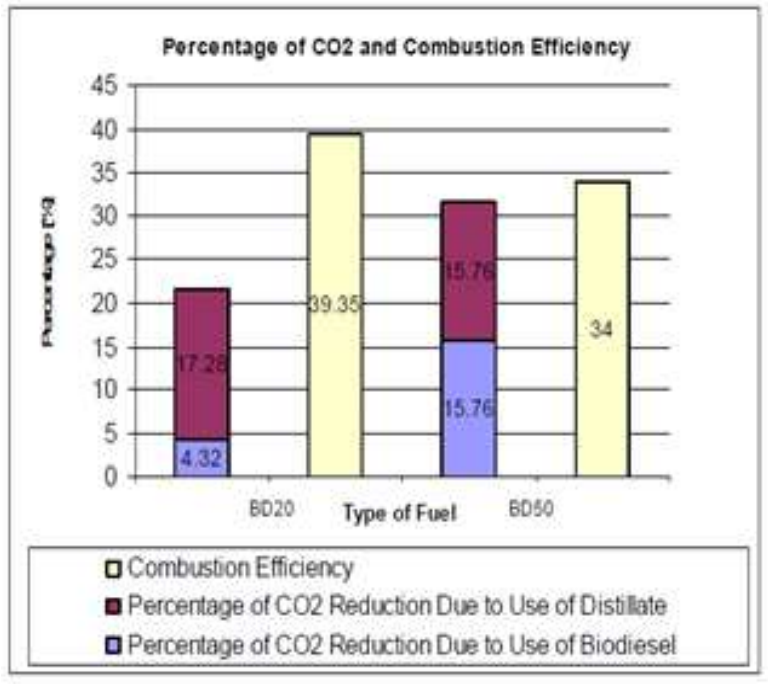

Figure 4: Percentage of $\mathrm{CO} 2$ Emission Reduction due to the Presence of Biodiesel[20]. 


\section{Conclusion}

The review of the emission and performance characteristic of biodiesel burner system clearly indicated that this form of alternative fuel can be an attractive renewable alternative energy source for burner system. Physical and chemical properties of biodiesels can have significant effects on the combustion process, which will impact on the burner performance and emissions. For better performance and emission, the burner design should match the biodiesel characteristics. The search for cost-effective feedstock and processes to produce quality biodiesels must not only consider economic factors, but also focus on long term ecological and environmental issues. The possibilities to reduce the problems of higher toxic emission such as nitrogen oxide (NOx), carbon monoxide (CO) and particulate matters (PM) is achievable.

The biodiesel burner system cover a broad range parametric study of combustion control technologies of burner system with controlling the mixture formation for reducing the emissions, some of which, including water-in-diesel emulsions, specially design injection system are readily available, while other types require further investigations, are produced in very limited amounts or require to be specially designed. Even if it's only a limited influence on the reduction of fossil some of the emission, it is still valuable from an environmental point of view.

\section{References}

[1] H. S. Kaur Channi Harwinder Singh, "The Growing Importance of Biomass," IJREAS, vol. 2, no. 2, pp. 529-539, 2012.

[2] M. Mittelbach and S. Gangl, "Long storage stability of biodiesel made from rapeseed and used frying oil," J. Am. Oil Chem. Soc., vol. 78, no. 6, pp. 573-577, 2001.

[3] Amir Khalid, Norazwan Azman, Hanis Zakaria, B. Manshoor, Izzuddin Zaman, Azwan Sapit, Mutalib Leman, "Effects of storage duration on biodiesel properties derived from waste cooking oil", Applied Mechanics and Materials, Volume 554, 2014, Pages 494-499, DOI: $10.4028 /$ www.scientific.net/AMM.554.494.

[4] J. Charles E. Baukal, The John Zink Combustion Handbook. Taylor \& Francis, 2010.

[5] C. R. Gustafson, "Biodiesel: An Industry Poised for Growth?," Choices, vol. 18, no. 3, 2003.

[6] J. V. C. V. J. C. L. Torrensa E. C. Tellesa, A. B. Marianoa, and J. C. Ordonezb, "Biodiesel From Microalgae: The Effect Of Fuel Properties On Pollutant Emissions," Therm. Eng., vol. 7, no. 2, pp. 35-43, 2008.

[7] Amir Khalid, N.Tamaldin, M. Jaat, M. F. M. Ali, B. Manshoor, Izzuddin Zaman, "Impacts of biodiesel storage duration on fuel properties and emissions", Procedia Engineering, volume 68, 2013, Pages 225 - 230, Elsevier, 2013, DOI: 10.1016/j.proeng.2013.12.172.

[8] M. J. Haas, A. J. McAloon, W. C. Yee, and T. A. Foglia, "A process model to estimate biodiesel production costs," Bioresour. Technol., vol. 97, no. 4, pp. 671-678, 2006.

[9] K. Bozbas, "Biodiesel as an alternative motor fuel: Production and policies in the European Union,” Renew. Sustain. Energy Rev., vol. 12, no. 2, pp. 542-552, 2008.

[10] C. B. Granda, L. Zhu, and M. T. Holtzapple, "Sustainable liquid biofuels and their environmental impact," Environ. Prog., vol. 26, no. 3, pp. 233-250, 2007.

[11] G. R. de Souza, A. M. dos Santos, S. L. Ferreira, K. C. Ribeiro Martins, and D. L. Madolo, "Evaluation of the performance of biodiesel from waste vegetable oil in a flame tube furnace," Appl. Therm. Eng., vol. 29, no. 11, pp. 2562-2566, 2009.

[12] J. Charles E. Baukal, Industrial Burners Handbook, no. 1. Taylor \& Francis, 2003, p. p 15-52.

[13] M. J. R. M.S. Klassen L.D. Eskin and R.J. Roby, "Clean Combustion of Liquid Biofuels in Gas Turbines for Renewable Power Generation," Tech. Proc. Clean Technol. Conf. Trade Show, pp. 47-50, 2008.

[14] M. H. A. R. Mantari and M. N. M. Jaafar, "Performance of oil burner system utilizingvarious palm biodiesel blends," Int. J. Mech. Mater. Eng., vol. 4, no. 3, pp. 273-278, 2009. 
[15] M. S. Ashrul Ishak, M. N. Mohd Jaafar, and Y. A Eldrainy, "The effect of radial swirl generator on reducing emissions from bio-fuel burner system," Mod. Appl. Sci., vol. 3, no. 6, p. 45, 2009.

[16] Amir Khalid, M.D. Anuar, Yusri Ishak, B. Manshoor, Azwan Sapit, Mutalib Leman, Izzuddin Zaman, "Emissions characteristics of small diesel engine fuelled by waste cooking oil", MATEC Web of Conferences, Volume 13, 2014, Article number 06006, DOI: $10.1051 /$ matecconf $/ 20141306006$.

[17] C. T. Chong and S. Hochgreb, "Spray Combustion Characteristics of Palm Biodiesel," Combust. Sci. Technol., vol. 184, no. 7-8, pp. 1093-1107, 2011.

[18] G. Knothe, J. H. Van Gerpen, and J. Krahl, The biodiesel handbook, vol. 1. AOCS press Champaign, IL, 2005.

[19] G. Knothe, "Dependence of biodiesel fuel properties on the structure of fatty acid alkyl esters," Fuel Process. Technol., vol. 86, no. 10, pp. 1059-1070, 2005.

[20] T. E. Sann, K. Palanisamy, M. Nazrain, and N. A. Farid, "Study of Carbon Dioxide Emission during Combustion of Biodiesel.” ICEEE, pp. 65-70, 2006.

[21] S. Sawarimuthu, M. Jaafar, and M. Nazri, "Performance of various biofuel blends on burner system," J. Mek., no. 27, pp. 69-77, 2008.

[22] Amir Khalid, Keisuke Hayashi, Yoshiyuki Kidoguchi , Tomoaki Yatsufusa, "Effect of air entrainment and oxygen concentration on endothermic and heat recovery process of diesel ignition", (2011) SAE Technical Papers, DOI: 10.4271/2011-01-1834.

[23] H. K. Ng and S. Gan, "Combustion performance and exhaust emissions from the nonpressurised combustion of palm oil biodiesel blends," Appl. Therm. Eng., vol. 30, no. 16, pp. 2476-2484, 2011.

[24] M. A. Hess, M. J. Haas, T. A. Foglia, and W. N. Marmer, "Effect of antioxidant addition on NO x emissions from biodiesel," Energy \& Fuels, vol. 19, no. 4, pp. 1749-1754, 2005.

[25] Y. Yoshimoto and H. Tamaki, "Reduction of NOx and smoke emissions in a diesel engine fueled by biodiesel emulsion combined with EGR," SAE, pp. 1-649, 2001.

[26] R. O. Dunn, "Effect of antioxidants on the oxidative stability of methyl soyate (biodiesel)," Fuel Process. Technol., vol. 86, no. 10, pp. 1071-1085, 2005.

[27] M. Pugazhvadivu, "Studies on the effect of ethanol addition to biodiesel: Performance and emissions of a diesel engine," Indian J. Sci. Technol., vol. 2, no. 11, pp. 23-26, 2009.

[28] Y. Kidoguchi, T. Yatsufusa, and D. Nakagawa, "Improvement of Emissions and Burning Limits in Burner Combustion using an Injector on the Concept of Fuel-water Internally Rapid Mixing," Proc. 5th Eur. Combust. Meet., no. June, 2011.

[29] Y. K. Tomoaki Yatsufusa Kumura Tatsuya and Nakagawa Yoshiki, "Advantage of Using Water-Emulsified Fuel on Combustion and Emission Characteristics," 4th Eur. Combust. Meet. , vol. Wien, no. April, pp. 1-6, 2009.

[30] K. Kannan and M. Udayakumar, "NOx and HC emission control using water emulsified diesel in single cylinder diesel engine," ARPN J. Eng. Appl. Sci., vol. 4, no. 8, 2009.

[31] M. F. Sies, N. Mustaffa, H. Zakaria, H. bin Salleh, B. Manshoor, and A. Khalid, "A Review of the Concept of Fuel-Water Internally Rapid Mixing Injector in Burner System," in Applied Mechanics and Materials, 2014, vol. 465-466, pp. 296-301.

[32] K. B. S. Baghdar Hosseini A.R. Moghiman, Y. Khazraii, N. Nikoofal, "Experimental Comparison of Combustion Characteristic and Pollutant Emission of Gas oil and Biodiesel," Int. J. Mech. Mater. Eng. , 2010.

[33] S. A. Basha, K. R. Gopal, and S. Jebaraj, "A review on biodiesel production, combustion, emissions and performance," Renew. Sustain. Energy Rev., vol. 13, no. 6, pp. 1628-1634, 2009. 